\title{
Skeive liv
}

\author{
Felles fortellinger på tvers av forskjeller
}

\section{SAMMENDRAG}

Hva er det som trekkes frem som viktige hendelser når skeive skal fortelle om sine liv i Norge på 2oro-tallet? I denne artikkelen analyserer vi frem fellesnevnere på tvers av kvalitative intervjuer med 99 skeive personer med ulik bakgrunn og livssituasjon. Til tross for de mange ulikhetene mellom deltakerne var det noen overordnede tema som gikk igjen og fremstod som betydningsfulle på tvers av generasjoner og livssituasjoner: r) Erfaringer med å føle seg annerledes, 2) negative møter, 3) utforsking av identitet knytta til seksualitet og kjønn, 4) å komme ut som skeiv, 5) å komme inn i skeive fellesskap og 6) refleksjon rundt slektskap og familie. Disse viktige hendelsene kan være enkelthendelser i tid, samtidig som erfaringene repeteres gjennom livet både som hendelser og ved å fortelles frem som del av en skeiv livshistorie. På denne måten får hendelsene betydning ut over tiden og stedet de fant sted, og inngår i en situert skeiv selvfremstilling. Vi forstår de seks temaene som skeive metanarrativ som fremstår relevante når skeive skal fortelle om seg selv og sitt liv. I artikkelen bretter vi ut disse metanarrativene og noe av variasjonen i konkrete erfaringer som finnes i datamaterialet. Vi argumenterer for at disse viktige hendelsene kan forstås som et tidsbilde som sier oss noe om hvordan vi gjør oss forståelige for hverandre som skeive på 2oro-tallet.

Nøkkelord: skeiv, livshistorier, narrativ, viktige hendelser, levekår

NÅR SKEIVE PÅ 2OIO-tallet skal fortelle om sine liv, hva slags viktige hendelser er det som trekkes frem da? I denne artikkelen analyserer vi frem noen viktige fellesnevnere som dukker opp på tvers av nesten hundre kvalitative intervjuer med skeive personer i ulike aldre, fra ulike steder, 
og med svært ulik bakgrunn og livssituasjon. 20Io-tallet i Norge var preget av økt tverrpolitisk enighet om å støtte skeives rettigheter, konsolidering av formelle rettigheter, økt oppmerksomhet rundt transtematikker, og differensiering av betegnelser for kjønn og seksualitet. For de yngste deltakerne $\mathrm{i}$ vårt datamateriale var dette den eneste konteksten de hadde opplevd, mens de eldste - og flere av dem som har innvandrerbakgrunn - levde sin ungdomstid i en sosial kontekst hvor det å være skeiv var straffbart eller sett på som en psykisk lidelse. For de sistnevnte gruppene er derfor sammenlikninger mellom før og nå, og der og her, en del av livshistorien.

Intervjuene som danner grunnlaget for artikkelen ble gjennomført i ulike forskningsprosjekter der folk ble invitert til å fortelle om livene sine som skeiv. Deltakernes livssituasjoner og erfaringer varierte mye, men fellesnevneren var en eller annen form for skeiv identitet siden dette dannet utgangspunktet for rekruttering. De yngste deltakerne fortalte om erkjennelser, relasjoner og erfaringer som i stor grad var basert på her-og-nå-situasjonene. De eldre deltakerne derimot, fortalte i større sveip og med referanserammer som gikk over mange tiår.

Til tross for de mange ulikhetene mellom deltakerne, var det noen overordnede tema som gikk igjen og fremstod som betydningsfulle på tvers av generasjoner og livssituasjoner. Vi har kalt disse temaene for viktige hendelser $i$ skeive liv. Det er hendelser og livssituasjoner som deltakerne husker og løfter frem, som har fått betydning utover tiden og stedet de fant sted. Selv om temaene som løftes frem er fellesnevnere på tvers av datamaterialet, er variasjonen stor i de konkrete erfaringene.

\section{Teoretiske perspektiver}

I denne artikkelen analyserer vi seks overordnede og betydningsfulle tema i skeives selvfremstillinger: I) Erfaringer med å føle seg annerledes, 2) negative møter med andre som knytter seg opp til kjønn og seksualitet, 3) utforsking av identitet rundt kjønn og seksualitet, 4) det å komme ut som skeiv for sine nærmeste, 5) det å komme inn i skeive fellesskap og 6) refleksjon rundt slektskap og familie, inkludert vurderinger knytta til det å få barn. 
Vi har tatt utgangspunkt i begrepet "critical moments", eller viktige hendelser som vi har valgt å kalle det på norsk, som refererer til hendelser som enten forskeren eller deltakeren forstår som sentrale i livet og for identiteten (Thomson mfl. 2002, 339). Dette er et fleksibelt analytisk begrep som er godt egnet til empirinære analyser av livsløpsfremstillinger. Å lete etter hva deltakerne forteller frem som viktige hendelser har gjort det mulig for oss å lytte etter den enkeltes fortelling, og se disse i lys av tilgjengelige narrativ for skeive liv.

Vi bygger på et sosialkonstruksjonistisk perspektiv, hvor kjønn og seksualitet ikke er faste størrelser, men kategorier som virker i verden og i oss på bestemte måter (Butler I990; Foucault I984). Sosialkonstruksjonistiske perspektiver ligger også til grunn for vår forstålse av intervjuer som narrativ. Vi forstår livshistorier og fortellinger, ikke som oversettelser av liv til tekst, men som en del av selve livet. Vi har dessuten med oss et blikk for at viktige hendelser i livet kan skje på ulike tidspunkt, og søkt å unngå krononormative forståelser av livsløp (Freeman 20ıо). Vi skriver oss dermed inn i en kontekst av forskere med interesse for skeiv identitet og prosessen med å fortelle seg selv slik dette til enhver tid gjøres mulig (se for eksempel Bolsø 20ro; Hellesund 2008; Lundahl I998; Ohnstad 2009; Hammack \& Cohler 20II).

Viktige hendelser som å komme ut som skeiv eller posisjonere seg visa-vis en "normalitet" man ikke er en del av, kan være enkelthendelser i tid, men som, når den fortelles frem, har en performativ effekt: "Se, vi har denne erfaringen til felles", hvor den felles erfaringa skaper et kollektiv (Plummer 1990). Når vi har intervjuet folk har vi tatt utgangspunkt i en skeiv identitet, og dem vi har snakket med har snakket ut fra og inn i denne identiteten. Som blant annet Pia Lundahl (1998) påpeker, for å erfare og forklare skeiv identitet må man sette sine egne erfaringer inn i rammene av noe som er gjenkjennelig for andre, en skeiv representasjon, som ikke bare må læres, men som også er en pågående prosess.

Det som fremgår tydelig på tvers av intervjumaterialet er at det finnes mange elementer i folks historier som kan sies å være skeive metanarrativ, for eksempel å føle seg annerledes, å gjøre kjønn på andre måter enn dem som var forventa som barn, og vurderinger rundt åpenhet. Disse 
elementene finner vi igjen i Foucault $(1984,43)$ sin redegjørelse for hvordan "den homoseksuelle" ble kulturelt skapt. Når deltakerne forteller om seg selv som skeive, plasserer de seg inn i skeive metanarrativ. Dette kan utgjøre både produktiv motstand og bevarende disiplinering. Når vi strukturerer deltakernes erfaringer som vi gjør i denne teksten, er det et forsøk på å synliggjøre nettopp hvilke skeive metanarrativ som finnes akkurat her og nå, og som fremstår relevant når skeive skal fortelle om seg selv og sitt liv.

\section{Metode}

Analysene er basert på personlige intervjuer, noen intervju med par og fire fokusgruppeintervjuer med til sammen 99 skeive personer. Skeiv betyr i denne sammenhengen en selvidentifisering som noe annet enn heteroseksuell, og eventuelt også noe annet enn cis-person. Intervjuene som inngår i materialet er gjennomført i forbindelse med flere ulike forskningsprosjekter som forfatterne har gjennomført mellom $2014 \mathrm{og}$ 2018. Se tabell I for en oversikt over datakildene.

Det samlede kvalitative datamaterialet ble først analysert i sin helhet $\mathrm{i}$ arbeidet med rapporten "Skeive livsløp" (Eggebø, Stubberud \& Anderssen 2019). . Mens rapporten fokuserer på et bredt spekter av tema, har vi i denne artikkelen valgt å videreutvikle analysene ved å fokusere på det informantene forteller frem som - eller vi leser som - viktige hendelser (critical moments) (Thompson et al. 2002).

Som tabellen viser hadde de ulike forskningsprosjektene forskjellig fokus, men med skeive liv og erfaringer som fellesnevner. De fleste intervjuene hadde en nokså lik form: Vi stilte ett hovedspørsmål som deltakerne ble bedt om å fortelle fritt ut fra. I tillegg stilte vi oppfølgingsspørsmål til deltakernes egne fortellinger, og noen forhåndsdefinerte spørsmål knyttet til levekårstema som utdanning og arbeid, helse, relasjoner, åpenhet, diskriminering og vold. Felles på tvers av alle prosjektene var at deltakerne fortalte åpent og detaljert om livet. I fokusgruppene la vi til rette for en gruppediskusjon om henholdsvis utfordringer og muligheter ved å være skeiv med innvandrerbakgrunn, og begreper for kjønn og seksualitet og diskrimineringserfaringer i de 
Tabell 1. Antall informanter som inngår $i$ analysene fordelt på datakilde

(Eggebø, Stubberud E Anderssen, 2019).

\begin{tabular}{|c|c|c|}
\hline Prosjekt/datakilde & $\begin{array}{l}\text { Antall } \\
\text { informanter } \\
\text { som inngar i } \\
\text { foreliggende } \\
\quad \text { analyse }\end{array}$ & Fokus for prosjektet og datainnsamlingen \\
\hline $\begin{array}{l}\text { Den eneste skeive i bygda? } \\
\text { (Stubberud, Prøitz \& } \\
\text { Hamidiasl 2018) }\end{array}$ & I 2 & $\begin{array}{l}\text { Unge skeives bruk av kommunale helsetje- } \\
\text { nester og erfaringer med å vokse opp som } \\
\text { skeiv. Semistrukturert, med åpent introduk- } \\
\text { sjonsspørsmål og oppfølgingsspørsmål om } \\
\text { helsetjenester. }\end{array}$ \\
\hline Skeivt arkiv & 6 & $\begin{array}{l}\text { Livshistorieintervjuer med eldre skeive som } \\
\text { har fortalt om livet og om sin rolle i skeiv } \\
\text { aktivisme. }\end{array}$ \\
\hline $\begin{array}{l}\text { Skeiv på bygda (Eggebø, } \\
\text { Almlie \& Bye 2015) }\end{array}$ & 24 & $\begin{array}{l}\text { Hvordan deltakerne opplever det å bo på } \\
\text { mindre steder. }\end{array}$ \\
\hline $\begin{array}{l}\text { Levekår blant skeive med } \\
\text { innvandrerbakgrunn (Egge- } \\
\text { bø, Stubberud \& Karlstrøm } \\
\text { 2018), inkludert prosjektet } \\
\text { Alene og skeiv (Stubberud \& } \\
\text { Akin 2018) }\end{array}$ & 42 & $\begin{array}{l}\text { Åpne livshistorieintervju med spørsmål } \\
\text { om deltakerne kan fortelle om livet fra } \\
\text { barndommen og frem til i dag med fokus på } \\
\text { det å være skeiv. Materialet inkluderte også } \\
\text { fokusgruppeintervju. } \\
\text { I ”Alene og skeiv" forteller skeive enslige } \\
\text { mindreårige asylsøkere om erfaringer på } \\
\text { omsorgssentre og mottak i Norge, men også } \\
\text { mer overordnet om livet. }\end{array}$ \\
\hline $\begin{array}{l}\text { Nye individuelle intervju/ } \\
\text { parintervjuer }\end{array}$ & 7 & Åpne livshistorieintervju. \\
\hline Nye fokusgrupper & 8 & $\begin{array}{l}\text { Fokus på diskriminering, og begreper for } \\
\text { kjønns- og seksualitetsmangfold. }\end{array}$ \\
\hline Totalt & 99 & \\
\hline
\end{tabular}

to andre fokusgruppeintervjuene. For mer utfyllende informasjon om rekruttering, gjennomføring av intervjuene og etiske refleksjoner viser vi til de enkelte prosjektrapportene samt en samlet fremstilling i rapporten "Skeive livsløp" (Eggebø, Stubberud \& Anderssen 2019).

De 99 deltakerne som inngår i datamaterialet var mellom 16 og 87 år på intervjutidspunktet, de fleste rundt 20-30 år. Utvalget representerer bredde $\mathrm{i}$ bakgrunner og erfaringer når det gjelder landbakgrunn, etnisitet, funksjonsevne, alder, bosted, utdanning og sosial bakgrunn. 
Alle landets regioner er representert, med informanter bosatt både i de store byene og på små steder. Seks informanter oppga å ha ulike former for synlig eller ikke-synlig nedsatt funksjonsevne. Seks informanter har samisk bakgrunn. $4 \mathrm{I}$ har innvandrerbakgrunn, ${ }^{2}$ og blant disse er mange i en økonomisk vanskelig situasjon. De fleste i utvalget har høyere utdanning, og de yngste går på videregående skole.

I alle forskningsprosjektene gjorde vi først en empirinær analyse av datamaterialet, hvor formålet var å kartlegge sentrale tema i det samlede datamaterialet (Braun \& Clarke 2006; Thompson et al. 2002). Vi benyttet fremgangsmåten som Eggebø (2020) har kalt "kollektiv kvalitativ analyse" hvor forskergruppa i fellesskap går gjennom og gjør en grundig analyse av datamaterialet som danner grunnlaget for videre arbeid.

Basert på disse analysene vil vi i det følgende beskrive seks viktige hendelser i skeive liv. Disse seks temaene framstår som fellesnevnere i skeive liv, på tvers av andre ulikheter. Det betyr imidlertid ikke at livserfaringene er like. Innenfor hvert av temaene er det stor variasjon i hvilke konkrete erfaringer deltakerne forteller om. I det følgende vil vi beskrive disse felles temaene, og samtidig vise frem noe av den variasjonsbredden som finnes i livserfaringer knyttet til hvert enkelt tema.

\section{Å føle seg annerledes}

Et gjennomgangstema i fortellingene var en beskrivelse av en grunnleggende følelse av å være annerledes. For mange var dette en livslang følelse som de husket allerede fra barndommen. Deltakere som hadde vokst opp i forskjellige land og ulike tidsepoker fortalte relativt like historier om denne følelsen av annerledeshet. Annerledesheten handlet om å innse at man bryter med normer for kjønn og seksualitet, og dette kunne skje på ulike tidspunkt i livet.

For mange deltakere kretset annerledesheten rundt interesser eller begjær som tok andre former enn det som var forventet av dem. De beskrev at de som barn hadde det som av omgivelsene ble oppfattet som for feminine eller for maskuline interesser og preferanser. Kristiansen (2004, 8I) fant tilsvarende fortellinger blant de eldre homofile mennene han intervjuet, og han kaller disse fortellingene for forvarsler - "tegn 
på at kimen til den identiteten man senere utviklet, lå der allerede fra begynnelsen”. Vårt materiale viser at dette ikke bare gjelder for menn, men også for andre kjønn. Flere fortalte at de likte aktiviteter eller ville kle seg på måter som ble ansett som upassende for deres kjønn. Disse preferansene ble i mange tilfeller møtt med motstand av omgivelsene, inkludert foreldre og andre nære voksne.

Livshistoriene om det å skille seg ut som barn viser at mange ble møtt med negative reaksjoner fra omgivelsene, og at de gjennom disse reaksjonene ble oppmerksomme på at deres preferanser innebar normbrudd. Grue $(2018,60)$ peker på samme fenomen når det gjelder funksjonshemming og spør: "Hva er det normale barn? [...] det finnes tusenvis av måter å avvike fra normalen på. Vi merker det ikke før vi blir gjort oppmerksomme på det, men så slår skammen inn”. Mange av deltakerne beskrev følelsen av annerledeshet som smertefull. Dette koblet de til konkrete negative sanksjoner fra omgivelsene, ofte personer i nære relasjoner. Det kunne også handle om hetero- eller cisnormative antakelser som gjorde at de både åpent og mer subtilt ble gjort oppmerksom på at de skilte seg ut. For enkelte innebar dette skam. Barn som føler seg annerledes, og som ikke opplever at voksne rundt forstår deres situasjon eller bekrefter dem og deres opplevelser, har mer å tenke på enn andre barn, og de står mer alene med sine følelser.

Følelsen av annerledeshet baserte seg gjerne på flere hendelser i barndommen og senere i livsløpet. Det var en tilbakevendende erfaring og følelse som vedvarte gjennom livet for mange, eksempelvis knyttet til det å få barn som skeiv, leve alene eller ha normoverskridende kjønnsuttrykk. Annerledesheten mange erfarte i barndommen fikk gjenklang i erfaringene folk gjorde seg som voksne. Den opplevde annerledesheten ble fortalt fram som en del av fortellingen om en selv som skeiv. Samtidig kunne annerledesheten også handle om andre ting. Å føle seg annerledes var for noen knyttet til hudfarge, landbakgrunn, klassebakgrunn og funksjonsvariasjon. Flere av deltakerne, særlig de som brøt med funksjonsnormen og/eller ikke var hvite, understreket at disse formene for annerledeshet var og hadde vært viktigere for dem enn annerledesheten knyttet til det å bryte med hetero- og cisnormen. 
Erfaringen av annerledeshet preger skeive narrativ - også i de tilfellene der annerledesheten senere i livet får et positivt fortegn. Som barn har man ikke nødvendigvis verken livserfaring eller de emosjonelle og praktiske ressursene til å skaffe seg den bekreftelsen man kanskje trenger fra omgivelsene. Dette samsvarer med andre undersøkelser, blant annet Hammack og Cohlers (20II) amerikanske studie av ulike generasjoner skeive, som også viser at på tvers av generasjoner ser følelsen av annerledeshet ut til å vedvare. Det ser altså ser ut til å være noe kritisk ved opplevelsen av annerledeshet - enten den handler om det å bryte normer for kjønn og seksualitet eller om andre normbrudd.

\section{Negative møter}

Samtlige deltakere fortalte om møter med andre mennesker - det være seg nære, bekjente eller fremmede - hvor de hadde blitt møtt med en eller annen form for negativ, uønsket eller ubehagelig reaksjon fordi man bryter med normer for kjønn eller seksualitet. Det var stor variasjon i typen negative møter som deltakerne beskrev, som spant fra alvorlige hendelser i form av voldelig hatkriminalitet til negative kommentarer eller subtile bemerkninger. En fellesnevner var at både svært alvorlige og mindre alvorlige hendelser ble fortalt fram som viktige, i den forstand at erfaringene hadde fått konsekvenser for deltakernes liv og identitet.

Flere av deltakerne fortalte om slike negative møter knyttet til kjønn og seksualitet tidlig i livet. Dette omfattet vold eller trusler i forbindelse med å komme ut, men det var mer vanlig med erfaringer med mobbing. Mobbeforskningen viser at barn og unge som tilhører minoritetsgrupper som samer, seksuelle minoriteter, funksjonshemmede eller har innvandrerbakgrunn ser ut til å være mer utsatte for mobbing enn barn og unge som tilhører majoriteten (for en oversikt, se Lillejord et al. 20r4). Flere fortalte videre at de kjente til eller hadde vært vitne til at "homo" ble brukt som skjellsord, eller at andres brudd på normer for kjønn og seksualitet ble møtt med vold eller grove krenkelser. Deltakere fortalte også om negative møter hvor kjønn og seksualitet virket sammen med andre diskrimineringsgrunnlag.

Flere deltakere fortalte videre om hvordan kombinasjonen av erfarin- 
ger med mobbing, diskriminering, vold eller hatytringer, og kunnskap om at gruppen man tilhører diskrimineres, førte til frykt for negative møter. Deltakere i alle aldersgrupper beskrev at redselen for sanksjoner og negative møter begrenser handlingsrommet og livsutfoldelsen. En transkvinne i 20 -årene fortalte:

Jeg har ikke opplevd noe fysisk vold. Nå er jeg veldig forsiktig med å gå ute på natta, eller gå alene. Jeg er ikke så aktiv ute for tida, heller. [...] Jeg har jo hørt tusenvis av saker hvor ting har gått galt. Og jeg vet på en måte hva jeg skal unngå. Som å gå ute på natta alene. Det unngår du hvis du er fullsminka. Å gå ute som kvinne. Du kan unngå [...] spesielle grupper mennesker. Altså store guttegrupper som tydelig er berusa. Berusa mennesker generelt, egentlig, prøver du å unngå. Bakgater egentlig ting som alle unngår. Jeg drar også heller aldri på vors, eller nach, eller sånne ... drar helst aldri til mennesker jeg ikke kjenner.

Deltakeren fortalte om en sterk risikobevissthet knyttet til det å bevege seg i det offentlige rommet som kvinne og som synlig transperson. $\AA$ hele tiden måtte vurdere hvor ubehagelig eller farlig en situasjon kan bli, kan bidra til at man går rundt i en kontinuerlig tilstand av mobilisering, ofte kalt minoritetsstress (Brooks I98I; Meyer 2003). Minoritetsstress er den tilleggsbelastningen personer som tilhører marginaliserte grupper i samfunnet opplever i kraft av å tilhøre en eller flere slike grupper, og som kan gi seg utslag i, blant annet, psykisk uhelse. Når det gjelder minoritetsstress er det ikke gitt at det er et tydelig skille mellom å erfare negativ oppmerksomhet rettet mot en selv, og negative handlinger som er rettet mot andre. En kombinasjon av egne erfaringer og det å være vitne til diskriminering av andre i gruppa man tilhører, kan bidra til å skape frykt for potensielle krenkelser (Perry 20I4; Eggebø \& Stubberud 20I6, 34-35). Dette ser ut til å spille inn for deltakeren i sitatet over, som ikke har vært utsatt for fysisk vold, men som likevel tar en rekke forholdsregler.

Det er viktig å ha et blikk også for negative møter av mindre alvorlig karakter, som likevel får betydning i kraft av de gjentas gjennom livet. 
Et eksempel er en lesbisk kvinne i 40-årene som fortalte at hun stadig opplevde uønsket oppmerksomhet om privatlivet på arbeidsplassen: ”Jeg opplevde en gang at en kollega begynte å stille meg ekstremt intime spørsmål. [...] Mitt liv har vært gjenstand for debatt gjennom hele mitt yrkesaktive liv". Selv om mindre alvorlige hendelser ikke trenger å få særlig store konsekvenser for hverdagslivet der og da, vet vi at denne typen erfaringer kan ha stor innvirkning når det skjer gjentakende ganger gjennom livsløpet (Grue 2018; Hellesund 2008; Joof 2018, Synnes \& Malterud 20I9). Livshistoriene til deltakerne i dette prosjektet bekrefter dette.

Kort oppsummert tematiserte deltakerne et spenn av erfaringer som kan forstås som negative møter, fra subtile bemerkning til alvorlige hendelser som hatytringer og vold. Det fremgår tydelig at slike negative møter oppleves som en del av det å være skeiv, og er en del av en skeiv selvfremstilling. Dette sier både noe om at det å være skeiv fortsatt innebærer konkret risiko, og at denne risikoen skrives inn i selvforståelsen ved at de negative møtene resiteres.

\section{Seksuell identitetsutforsking og kritiske seksuelle møter}

I de fleste intervjuene fremsto seksuell identitetsutforsking som viktig både for cis- og transpersoner. Det handlet om å bli kjent med seg selv som et seksuelt menneske i samspill med andre. For skeive kan artikulering av identiteten henge sammen med den seksuelle utforskningen og erfaringene man gjør seg sammen med andre. Dette vil, gitt et cisog heteronormativt samfunn, ikke nødvendigvis være tilfelle for streite ungdommers seksuelle utforsking på samme måte. Det er dermed ikke bare begjæret i seg selv i samspill med andre som utforskes, men også uro, en følelse av annerledeshet, og et ønske om å artikulere en identitet og tilhørighet. Deltakerne beskrev lignende erfaringer knyttet til behovet for identitetsutforsking, uavhengig av hvilket tidspunkt i livet de kom ut på.

En av deltakerne, som på intervjutidspunktet var i slutten av 30-åra, fortalte at det var først sent i 20 -åra, etter at han flyttet fra hjemplassen, at han fikk mulighet til å leve ut sin homofile identitet. Han fortalte at 
han oppførte seg som en tenåring i denne fasen: Han drakk, festet og hadde mange sexpartnere hvor han testet egne grenser og begjær. Han beskrev dette som en viktig fase i livet, hvor han for første gang hadde mulighet til å orientere seg i et skeivt miljø. Selv om han beskrev perioden som intens, fremstår det også som om den positive seksuelle utforskinga hadde noe helbredende over seg; de seksuelle og romantiske relasjonene var ikke bare flyktige møter, de ble også inngangsporten til et nettverk av skeiv subkultur som han identifiserte seg med og ønsket å være en del av.

Kritiske seksuelle møter, som en del av seksuell utforsking, kan være positivt slik som deltakeren over beskrev. Samtidig beskrev flere av de unge skeive guttene og mennene samt transkvinnene en til dels aggressiv sjekkekultur på nett. Her ble både det å være ung og ny på slike arenaer fetisjert av andre, gjerne menn som var eldre enn dem selv (se også Stubberud, Prøitz \& Hamidiasl 20I8). Flere av de skeive kvinnene fortalte dessuten om fetisjering, hyperseksualisering og trakassering knyttet til det å være svart kvinne, men da i streite miljø. I disse tilfellene blir seksualitet, hudfarge og rasistiske stereotypier vevd sammen. Andre deltakere fortalte om å få tilbud om å bytte sex mot penger. Noen deltakere fortalte om seksuelle opplevelser som de kanskje tenkte var ok der og da, men som i etterkant opplevdes negative. Enkelte beskrev seksuelle og romantiske relasjoner som åpenbart var preget av store maktforskjeller, slik som relasjonene mellom homofile enslige mindreårige asylsøkere og eldre, økonomisk privilegerte norske menn (Stubberud \& Akin 20r9). Flere av deltakerne beskrev dessuten alvorlige seksuelle overgrep, både i barndommen og som voksen.

Stereotypisering, seksuell trakassering, krenkelser og seksuelle overgrep begrenser handlingsrommet for seksuell utforsking på egne premisser. Dette er også uttalt blant de av deltakerne som forteller om rasialisert fetisjering og trakassering. For unge, både blant deltakerne i denne studien og i annen forskning, ser det ut til å ligge en sårbarhet ved å gå inn på ulike arenaer som seksuelt uerfaren og samtidig på søken. Det å posisjonere seg i skeive sammenhenger, inkludert på datingmarkedet, og etablere seksuelle relasjoner til andre skeive, kan være en viktig del av det å begynne å leve et skeivt liv. Men sårbarheten kan av og til 
utnyttes av de som er mer erfarne. Det er ikke gitt at unge skeive har tilstrekkelig seksuell handlingskompetanse til å utforske seksuell identitet på trygge måter, eller at de har emosjonelle eller materielle ressurser til å mestre seksuelle risikosituasjoner (Hegna \& Pedersen 2002, 40-4I; Mossige et al. 2008, 32).

Både fortellingene til deltakerne $\mathrm{i}$ vår studie og den eksisterende forskningen peker på flere spørsmål som bør besvares. For eksempel, er unge skeive særlig sårbare i sin seksuelle utforskingsprosess? Disse spørsmålene har til dels vært undertematisert både i forskning og i skeive organisasjoner. Etter vårt syn er tiden moden for å tematisere denne typen problemstillinger nå når det er bedre tilgang på formelle rettigheter og en generelt sterkere posisjon for skeive i det norske samfunnet.

\section{Å komme ut}

Å komme ut betyr å si til andre - eller la andre forstå - at man er eller har en identitet som skeiv i en eller annen form. Fortellinger om å komme ut er en sentral del av en moderne skeiv identitetskonstruksjon, og slike historier og spørsmålet om åpenhet er viktige tema i den skeive forskningen (Hellesund 2008). Dette gjenspeiler seg også i intervjuene i denne studien, der de fleste inneholder et metanarrativ om det å komme ut som skeiv. Det er særlig fortellinger om første gang man valgte å være åpen overfor sine nærmeste - oftest foreldre eller nære venner - som spiller en viktig rolle i livshistorien. Samtidig som dette metanarrativet figurerer, er det stor variasjon i de konkrete fortellingene og erfaringene. Hvordan man ble møtt i komme-ut-situasjonen synes videre å få betydning for både relasjonene til de man er åpen overfor, og derigjennom for langsiktige livsløpsbaner.

Et eksempel er en transkvinne i 50-årene som fortalte om hvordan hun hadde forsøkt å leve åpent som kvinne da hun var i tenårene. Hun ble møtt med negative reaksjoner fordi hun hadde et kjønnsuttrykk og en kjønnsidentitet som ikke samsvarte med kjønnet hun ble tildelt ved fødselen. Disse reaksjonene gjorde at hun de neste tiårene ikke tok sjansen på å leve åpent. Hun fortalte: 
Jeg var på folkehøyskole i I 7 års-alderen, og jeg var litt ute [av skapet] der. Jeg fikk noen bakoversveiser som gjorde at jeg tenkte at det der skal jeg fanden ikke gjøre noe mer. For det er direkte farlig. Selv i et såpass liberalt, progressivt miljø som jeg var i. [...] Jeg ble jo skremt grundig inn i skapet.

Deltakeren hadde tatt sjansen på å være åpen fordi hun befant seg i et tilsynelatende liberalt miljø, og antok at det kom til å være trygt. Det viste det seg imidlertid ikke å være, og det fikk store konsekvenser for det videre livsløpet for henne. Hun gikk inn i skapet og skjulte sin kjønnsidentitet og kjønnsuttrykk for omverdenen til hun var i 40-årene.

Deltakernes fortellinger viser at det å komme ut, langt ifra er noe som skjer bare én gang (Sedgwick 1990). De av oss som lever skeivt, må ta stilling til spørsmålet om åpenhet i svært mange nye relasjoner vi inngår i, det være seg private eller profesjonelle relasjoner. Åpenhet er også ofte situasjonsspesifikk, og det er for mange ikke snakk om et enten-eller (se for eksempel Malterud \& Bjørkman 2or6). Flere deltakere fortalte om situasjoner og relasjoner hvor de vurderte om de skulle være åpne eller ikke. I noen tilfeller overhørte de negative kommentarer rettet mot andre skeive, og dette gjorde at de vegret seg for å være åpen.

Det er ikke uventet generasjonsforskjeller i hvordan man forholder seg til åpenhet og erfaringer med dette. I dag kan det se ut til å være en sosial norm om at åpenhet er en forutsetning for å leve et godt liv som skeiv, mens det motsatte var tilfelle for 50-6o år siden. Dagens åpenhetsnorm er likevel noe omdiskutert. I en studie av likekjønnsrelasjoner på I900-tallet har for eksempel Kristiansen (2008) stilt spørsmål ved om åpenhet - slik det gjerne forstås i dag - er en forutsetning for å leve gode skeive liv. Han har vist at det også før homokampen i siste halvdel av I90o-tallet var mulig å leve gode liv som likekjønnspar, forutsatt diskresjon og stilltiende aksept. Brantsæter (I990) skiller mellom ulike former for åpenhet når det gjelder seksuell orientering som noe man sier, noe man gjør, eller noe man signaliserer. Hegna, Kristiansen og Moseng $(\mathrm{I} 999,47)$ differensierer mellom ulike former for åpenhet, og understreker at det er forskjell mellom det å skjule en seksuell identitet, og det å 
skjule (seksuelle) relasjoner med personer av samme kjønn. Dette er noe flere av særlig de eldre informantene i vårt materiale tematiserer.

Flere har pekt på at det å vedkjenne seg sin seksuelle orientering overfor seg selv og andre er en betingelse for et fullverdig liv og god helse (McNair, Szalacha \& Hughes 2or r), mens det å skjule sin seksuelle orientering kan påvirke både levekår, identitet, mestring og helse på negativ måte (Meyer 2003). Samtidig er det ikke gitt at sammenhengen mellom åpenhet og god helse er like sterk for alle grupper skeive dersom åpenhet er forbundet med risiko for forfølgelse, vold, diskriminering og brutte relasjoner til familie, venner og nettverk (Eggebø, Stubberud \& Karlstrøm 2018, 7I). Kristiansen (2008, 214) har vist at ikke alle skeive opplevde kravet om eksplisitt åpenhet i kjølvannet av frigjøringskampen som et gode og at mange i generasjonen som ble voksne på 1940- og I950-tallet, opplevde åpenhetskravet som moraliserende og ekskluderende. Den diskresjonskompetansen de hadde opparbeidet seg gjennom flere tiår, ble nå redusert til noe suspekt og latterlig.

Det som synes å være likheter på tvers av generasjoner, er først og fremst opplevelsen av dramatikk rundt det å si fra til sine nærmeste at man er skeiv; man kvir seg, og erfaringene huskes som gode eller som smertefulle. For det andre er en likhet på tvers av generasjoner at vennerelasjoner for mange opplevdes som et tryggere sted enn familierelasjoner å reflektere over identitetsspørsmål og øve seg på å artikulere sin seksuelle orientering og kjønnsidentitet. Å komme ut overfor foreldre, derimot, syntes å kunne være mer komplisert (også på tvers av generasjoner). Noen fortalte om foreldrenes støtte og forståelse, andre om foreldrenes forbløffelse og negativitet. Variasjonen er stor, og det er eksempler på både positive og negative erfaringer blant de eldste og de yngste, blant de med majoritetsbakgrunn og blant de med etnisk minoritetsbakgrunn, blant de som er bosatt på små steder og blant de som bor i større byer.

En spesiell utfordring syntes å være å komme ut overfor egne barn og samlivspartnere. Skeive deltakere som hadde etablert heteroseksuelle parrelasjoner, og transpersoner som levde i tråd med cisnormer og som også hadde fått barn i dette parforholdet, fortalte om vanskelige 
åpenhetsprosesser og om samlivsbrudd og i noen tilfeller flerårige og vanskelige relasjoner til barn eller (tidligere) partner.

Med utgangspunkt i deltakernes fortellinger fremstår erfaringen med å komme ut som en viktig hendelse i skeive liv. Minnet om første gang man kom ut var en tydelig referanse for mange av informantene. Dette kan være en konsekvens av at det å komme ut, er noe man må gjenta i stadig nye relasjoner (Sedgwick 1990). Erfaringene med slike komme ut-prosesser fortsetter derfor å være relevante gjennom gjentakelser gjennom livet.

\section{Å komme inn i skeive fellesskap}

Det å identifisere seg som skeiv for mange innebære at man føler seg annerledes, og kommer ut overfor omverdenen som en som bryter med heteronormative forventninger. Men annerledesheten og bruddet innebærer også en mulighet for å komme inn i en skeiv verden (Siverskog 20r6; Siverskog \& Bromseth 2019). Seksuell orientering er for mange ikke bare et spørsmål om hvem man tiltrekkes av, har sex med og er sammen med, det kan også være en identitet som gir tilhørighet til en gruppe. Å komme ut handler om å gi seg til kjenne som skeiv - for andre eller for seg selv, og å re-orientere seg selv og livet sitt i relasjon til et skeivt miljø (Ahmed 2006).

$\AA ̊$ orienter seg mot skeive fellesskap ble beskrevet som en viktig hendelse i livene til mange av deltakerne og er noe som eksplisitt trekkes frem når deltakerne skal fortelle om seg selv som skeive. Vi har dermed inkludert det å komme inn i skeive fellesskap som et av metanarrativene i skeives livsfortellinger. Overordnet handler disse fortellingene om å sette egne erfaringer inn i en større sammenheng, som danner grunnlaget for skeive fellesskap. Det å tre inn i skeive fellesskap handler på denne måten både om å fortelle frem seg selv på forståelige måter for andre skeive, men også om å bli normal i eget liv (Hegna, Kristiansen \& Moseng I999, I I; Anderssen \& Malterud 2013, 97; Synnes \& Malterud 2019). Vi mener at det er viktig å ha blikk for "komme inn"-delene av "komme ut"-prosessene. Dette omfatter også et blikk for hvilke utfordringer det å tre inn i skeive nettverk kan by på (jamfør å bli utnyttet, se over). 
Det å komme inn i eller bygge opp et skeivt nettverk kan ta tid og kreve innsats. Deltakerne fortalte om det å finne frem til, eller selv skape seg sine egne skeive nettverk. For mange innebar det å forflytte seg fysisk, gjerne bort fra oppvekstfamilie eller hjemplasser, til større byer eller andre land. Noen manglet skeive nettverk eller åpne og synlige skeive på stedet de vokste slik at de måtte forflytte seg, konkret stedligog i mange tilfeller også mentalt. Kanskje handler en slik fortelling om forflytning ikke bare om det stedlige, men også om muligheten til å se for seg en god fremtid. Som Muñoz har påpekt: "Queerness is not yet here. Queerness is an ideality. Put another way, we are not yet queer. We may never touch queerness, but we can feel it as the warm illumination of a horizon imbued with potentiality" (Muñoz 2009, I; se også Jones 2013). Det flyktige i det skeive er kanskje nettopp det som gjør at forflytningen oppleves som ikke bare en nødvendig forutsetning for mange av deltakerne, men også en mulighet.

Tilgang til skeive nettverk forutsetter noen grad av åpenhet. Mange deltakere beskrev kontekstspesifikk åpenhet, i noen tilfeller veldig todelte liv hvor deltagelse i skeiv subkultur var én viktig del av livet, uten at de nødvendigvis var åpne på andre arenaer som for eksempel på arbeidsplassen eller i familien. En informant fortalte hvordan hun og partneren hadde praktisert diskresjon over mange år. Da partneren døde, endret dette seg:

Det første jeg gjorde da Hanna døde var å dra på lesbisk leir (...). Da var jeg seksogfemti år. Da følte jeg må en måte at jeg var fri til å gjøre sånt. Fordi at jeg hadde tatt visse hensyn fordi Hanna ville jo ikke prate noe offentlig og ... nei. Så da følte jeg liksom at jeg kunne snakke høyt om det, da.

Det å snakke høyt om å leve med en annen kvinne var med andre ord noe deltakeren og partneren hadde vært uenige om. Det at deltakeren oppsøkte lesbiske fellesskap etter partnerens død kan forstås på flere måter. Ikke bare innebar det å bevege seg bort fra en diskre livsstil, det innebar også å fortsette å leve lesbisk, også etter partnerens død (se Bromseth 2015 om fellesskap mellom eldre lesbiske kvinner). 
Det å orientere seg mot skeive fellesskap var altså noe mange deltakere snakket om, samtidig som de konkrete erfaringene varierte mye. Analysene våre peker i samme retning som annen forskning når det gjelder hvilke funksjoner skeive nettverk har for folk. For det første utgjør skeive nettverk viktige politiske fellesskap (Bromseth 2015, 72). For det andre danner de grunnlaget for gruppetilhørighet som kan være viktigfor å håndtere og beskytte seg mot diskriminering og minoritetsstress (Eggebø \& Stubberud 20I6). For det trede kan skeive nettverk fylle en funksjon som valgt familie, noe som kan være viktig ettersom flere deltakere tematiserte både frykt for ensomhet i alderdommen og dårligere tilgang på nettverk gjennom oppvekstfamilie eller egenetablert familie (van Wagenen, Driskell \& Bradford 2013).

Samtidig som skeive nettverk ble beskrevet som viktig, var det ikke alle som hadde like god tilgang på, glede eller nytte av disse nettverkene. Dette kunne handle om at det ikke fantes skeive nettverk i nærheten, slik at man måtte skape dem selv. Blant annet forteller to unge skeive med samisk bakgrunn om hvordan de har markert seg i lokalmiljøet for å bli den rollemodellen de selv opplevde at de manglet. Et annet moment er at eksisterende skeive nettverk ikke nødvendigvis fungerer for alle, eksempelvis bifile som levde heterofilt. Det var imidlertid særlig de som tilhører flere minoritetsgrupper som trakk frem dette. En av dem artikulerte særlig tydelig at hun ble utsatt for betydelig mer rasisme enn homofobi i hverdagen, rasisme også i skeive fellesskap, og at for henne var de antirasistiske fellesskapene viktigere (se også Eggebø, Stubberud \& Karlstrøm 2018). Både skeive med funksjonsnedsettelser og rasialiserte skeive eller skeive som tilhørte etniske eller religiøse minoriteter, artikulerte dette spesielt tydelig. Også flere av de eldre deltakerne beskrev en opplevelse av å ikke passe inn i de skeive fellesskapene (se også Siverskog \& Bromseth 2019, Io).

\section{Refleksjon rundt slektskap og familie}

Refleksjoner rundt slektskap og familie er noe som figurerer i fortellingene til deltakerne i denne studien. Flere av deltakerne i 30-åra og eldre beskrev hvordan de, da de kom ut overfor foreldre spesielt, ble møtt med 
bekymringer knyttet til at de kom til å leve et ensomt liv, og at de ikke kom til å kunne få barn. Selv om flere av deltakerne også levde som single og uten barn - og levde godt med det - skriver denne bekymringen seg fra en bestemt historisk og geografisk kontekst som med introduksjon av partnerskaps- og deretter ekteskapsloven, og lesbiskes mulighet til assistert befruktning, nå er en annen. Dermed tar spørsmål knyttet til slektskap og familierelasjoner noen andre former nå.

Spørsmål som knytter seg til slektskap har vært sentral i skeiv forskning på samme måte som det har vært sentralt i skeive liv (se for eksempel Butler 1990; Freeman 2007). Skeiv forskning om slektskap handler ikke bare om å få barn, men også om relasjoner til partnere samt ulike typer vennskaps- og slektskapsrelasjoner (for en diskusjon, se for eksempel spesialnummeret av lambda nordica no. 2-3 2019).

Ikke overraskende beskrev deltakerne i denne studien også et mangfold av ulike måter å organisere sine singel- og samliv på. Fellesnevneren var at mange reflekterte rundt det de opplever som samfunnets ofte trange normer, og sine egne liv sett i lys av disse. To av deltakerne, et mannlig par i 30-åra med barn, fortalte:

Informant I: Men vi er nok litt sånn... trauste begge to, litt sånn A4-personer [ordinære], rett og slett. (...) Men samtidig er vi nok på en måte det friske pustet i gata her.

(...) Men hvor vidt de tenker på det, det vet jeg ikke. Men de har hvert fall ikke gitt uttrykk for det, liksom.

Informant 2: Men så har du jo andre naboer her, som kanskje har bodd her en stund og som kanskje har litt større barn. De tenker nok at vi skiller oss litt ut, ja. De synes det er litt eksotisk, tror jeg.

Informant r: Vi liker nok å forsvinne litt, begge to. Så vi ville ikke skille oss sånn ut.

Sitatet viser spennet mellom på den ene siden ønsket om og opplevelsen av å være vanlig og ikke skille seg ut, og på den andre siden følelsen av å være annerledes, og ha andres blikk på seg som et eksotisk innslag i gata.

Det var store variasjoner i de konkrete erfaringene blant deltakerne 
knytta til hvorvidt den enkelte ønsket eller hadde mulighet til å leve "vanlig". Noen, slik som deltakerne i sitatet over, ønsket et "vanlig" liv. For andre var ikke det "vanlige" et mål, og det skeive kunne i noen tilfeller henge sammen med eksempelvis det å leve utenfor parnormen (Roseneil et al. 2020), som polyamorøs eller demiseksuell. Fellesnevneren var likevel at refleksjoner omkring slektskap og familie for veldig mange utspiller seg i dette vanlig/uvanlig-spennet.

\section{Avsluttende refleksjoner}

Analysene i denne teksten baserer seg på materiale fra flere undersøkelser og datainnsamlinger. På tvers av veldig ulike erfaringer, posisjoner og generasjoner, har vi identifisert noen viktige fellestrekk i folks fremstilling av seg selv som skeive. I denne teksten har vi, med utgangspunkt i intervjuer med 99 skeive utført i løpet av 2oro-tallet i Norge, analysert frem seks viktige hendelser i skeive liv: Å føle seg annerledes, negative møter, seksuell identitetsutforsking og kritiske seksuelle møter, å komme ut, å komme inn i skeive fellesskap og refleksjon rundt slektskap og familie.

Under et forskningsintervju om skeive liv, over en øl på en skeiv bar, i garderoben etter en skeiv volleyballturnering, i det skeive koret, i avisintervjuer og bøker forteller skeive folk om seg selv, sine opplevelser og minner, og hvordan ytre begivenheter og indre erfaringer ser ut til å ha har formet oss/dem (se blant annet Plummer 1995). I intervjuene som denne teksten bygger på ba vi deltakerne snakke om seg selv som skeive. I dette ligger en bestilling: gjør deg selv gjenkjennelig for meg som skeiv. Livshistorier fortelles gjennom etablerte kulturelle narrativ, og slik gjør vi oss forståelige for hverandre samtidig som vi skaper oss selv (Hustvedt 20II; Muñoz 2009; Hammack \& Cohler 20II).

I materialet ser vi spor av noe stabilt på tvers av generasjoner og bakgrunn, og dette mener vi utgjør metanarrativ som skeive og andre inngår $i$, og som kan forstås som en del av vår samtid. Det betyr ikke nødvendigvis at det finnes noe skeivt som er radikalt annerledes enn det streite, eller at det ikke kan være stor overlapp i erfaringene til skeive og ikke-skeive (se for eksempel Bolsø 20Iо). Det skeive kan 
også komme i bakgrunnen til fordel for andre deler av identiteten eller erfaringene knytta til for eksempel funksjonsnedsettelse eller rase. Det skeive forsvinner ikke, men kan trumfes av andre diskrimineringsgrunnlag som i noen tilfeller kan skape både flere problemer og sterkere (behov for) tilhørighet.

Vi lette etter, og fant, imidlertid at noen viktige hendelser ser ut til å ha betydning i livshistoriene til skeive personer på 20ro-tallet i Norge. Det finnes åpenbart store forskjeller i erfaringer mellom deltakerne. For eksempel, for noen var ikke det å komme ut noen stor sak, mens det for andre ble en definerende negativ hendelse i livet. Disse ulike erfaringene er det som sier mest om den enkelte person og hens liv. Poenget er imidlertid også at på tvers av variasjonen i konkrete erfaringer finnes metafortellingene, som vi i denne teksten har trukket ut som overskrifter. Metafortellingene utgjør narrativ som er tilgjengelige når deltakerne skal gjøre seg forstålig for seg selv og for oss som forskere på temaet skeivhet. Når deltakerne forteller og vi analyserer deres fortellinger, så samproduseres og forsterkes også metanarrativene. På denne måten deltar også vi som forskere i produksjonen av historier og metanarrativ (Plummer 1995). Vi leser temaene som trekkes frem på tvers av materialet som sentrale komponenter i skeives fortellinger om seg selv i vår samtid.

De viktige hendelsene vi har trukket frem her kan forstås som et tidsbilde: De sier noe om hvilke fortellinger som er tilgjengelige i den aktuelle sosiale og historiske konteksten. I andre kontekster og tidsperioder vil det kunne være andre fortellinger som er tilgjengelige (se blant annet Plummer 1995 for en diskusjon). På tvers av dels store forskjeller finnes det noen felles fortellinger om skeive liv, noen metanarrativ som folk griper til. Disse fortellingene sier oss noe om at det er slik vi gjør vi oss forståelige for hverandre som skeive nå, dette er det vi trekker frem når vi legger vekt på vår skeive identitet. Med denne artikkelen ønsker vi å bidra til et empirisk basert språk for å snakke om det skeive, slik det ser ut i folks liv nå. 
ELISABETH STUBBERUD er førsteamanuensis i kjønns- likestilling- og mangfoldsstudier ved Norges teknisk-naturvitenskapelige universitet. Hun har den senere tid blant annet jobbet med en landsdekkende studie av levekår blant lhbtis-befolkningen i Norge. Hun er også involverte i skeiv aktivisme.

HELGA EGGEB $\varnothing$ arbeider som seniorforsker ved Nordlandsforskning. Hun har de siste årene forsket på migrasjon, aldring og levekår blant skeive, herunder skeive på bygda, skeive med innvandrerbakgrunn og en landsdekkende spørreundersøkelse.

NORMAN ANDERSSEN er professor i sosialpsykologi ved Universitetet i Bergen og forsker I ved NORCE Norwegian Research Centre. Han har de siste årene forsket om befolkningens holdninger til skeive, levekår blant lhbtis-personer og hvordan primærhelsetjenesten møter deprimerte pasienter.

\section{REFERANSER}

Ahmed, Sarah. 2006. Queer Phenomenology. Durham: Duke University Press.

Anderssen, Norman \& Kirsti Malterud. 2013. Seksuell orientering og levekår. Bergen: UniHelse.

Bolsø, Agnes. 2010. Folk flest er skeive. Oslo: Forlaget Manifest.

Brantsæter, Marianne. I990. Om kjønnets logikk-i et lesbisk perspektiv: Intervju med lesbiske kvinner om deres erfaringer i arbeidslivet. Hovedoppgave, Sosiologisk Institutt, Universitetet i Oslo.

Bromseth, Janne. 20I5. "Äldre lesbiska, bisexuella och trans-feministers berättelser om vänskap och lesbisk feministisk gemenskap över tid och rum." lambda nordica $20(4)$ : 45-8I.

Brooks, Virginia R. 198I. Minority Stress and Lesbian Women. Lexington: Lexington Books, D.C. Heath and Company.

Butler, Judith. 1990. Gender Trouble: Feminism and the Subversion of Identity. New York: Routledge.

Eggebø, Helga. 2020. ”Kollektiv Kvalitativ Analyse.” Norsk sosiologisk tidsskrift 4(2): Io6-22. https://doi.org/I0.1826r/issn.2535-2512-2020-02-03.

Eggebø, Helga, Maria Almli \& Marte T. Bye. 2015. Skeiv på bygda. Nordfold: Forlaget Nora. 
Eggebø, Helga \& Elisabeth Stubberud. 2016. Hatefulle ytringer delrapport II: Forskning på hat og diskriminering. Oslo: Institutt for samfunnsforskning.

Eggebø, Helga, Elisabeth Stubberud \& Henrik Karlstrøm. 2018. Levekår blant skeive med innvandrerbakgrunn i Norge. Bodø: Nordlandsforskning.

Eggebø, Helga, Elisabeth Stubberud \& Norman Anderssen. 2019. Skeive livsløp. En kvalitativ studie av levekär og sammensatte identiteter blant lhbtis-personer i Norge. Bodø: Nordlandsforskning.

Freeman, Elizabeth. 2oro. Time Binds: Queer Temporalities, Queer Histories. Durham \& London: Duke University Press.

- 2007. "Queer Belongings: Kinship Theory and Queer Theory." I A Companion to Lesbian, Gay, Bisexual, and Transgenders Studies, redigert av George Haggerty og Molly McGarry, 295-3r4. Hampshire: Blackwell Press.

Foucault, Michel. 1984. The History of Sexuality: 1 . Harmondsworth: Penguin.

Giertsen, Merethe \& Norman Anderssen. 2007. ”Time Period and Lesbian Identity Events: A Comparison of Norwegian Lesbians across 1986 and 2005. The Journal of Sex Research 44(4): 328-39. https://doi.org/10.1080/00224490701586698.

Grue, Jan. 2018. Jeg lever et liv som ligner deres. Oslo: Gyldendal.

Halberstam, J. Jack. 2005. In a Queer Time and Place: Transgender Bodies, Subcultural Lives. New York \& London: New York University Press.

Hammack, Philip \& Bertram Cohler. 2or r. "Narrative, Identity, and the Politics of Exclusion: Social Change and the Gay and Lesbian Life Course." Sexuality Research and Social Policy: Journal of NSRC 8(3): I62-I82. https://doi.org/Io.1007/SI3I78-or Ioo6o-3

Heaphy, Brian, Andrew K. T. Yip \& Debbie Thompson. 2004. "Ageing in a Nonheterosexual Context." Ageing and Society 24(4): 88I-902. https://doi.org/ro.ror7/ Sor 44686Xo30or6oo

Hellesund, Tone. 2008. Identitet på liv og død. Oslo: Spartacus.

Hegna, Kristinn, Hans Wiggo Kristiansen \& Bera U. Moseng. 1999. "Levekår og livskvalitet blant lesbiske kvinner og homofile menn." Nova-rapport I/99. Oslo: Nova.

Hegna, Kristinn \& Willy Pedersen. 2002. Sex for overlevelse eller skyggebilder av kjarlighet? Oslo: Nova.

Jones, Angela. 2013. A Critical Inquiry into Queer Utopias. New York: Palgrave Macmillan.

Kristiansen, Hans Wiggo. 2004. Kjerlighetskarusellen. Sosialantropologisk institutt, Universitetet i Oslo.

—. 2008. Masker og motstand: diskré homoliv i Norge 1920-1970. Oslo: UniPub.

Björklund, Jenny \& Ulrika Dahl (red.). 2org. Spesialnummer: "Queer Kinship Revisited." lambda nordica $24(2-3)$.

Lillejord, Sølvi, Erik Ruud, Peder Fischer-Griffiths, Kristin Børte \& Asle Haukaas. 2014. Forbold ved skolen med betydning for mobbing. Oslo: Kunnskapssenter for utdanning. 
Lundahl, Pia. 1998. Lesbisk identitet. Stockholm: Carlsson.

McNair, Ruth, Laura A. Szalacha \& Tonda L. Hughes. 20r r. "Health status, health service use, and satisfaction according to sexual identity of young Australian women." Women's Health Issues 2I(I): 40-47. https://doi.org/Io.1016/j.whi.2010.08.002

Malterud, Kirsti og Mari Bjørkman. 2or6. ”The invisible work of closeting: A qualitative study about strategies used by lesbian and gay persons to conceal their sexual orientation". Journal of Homosexuality 63 (10): 1339-54. https://doi.org/10.1080/oo9I 8369.2016.II57995

Meyer, Ilan H. 2003. "Prejudice, Social Stress, and Mental Health in Lesbian, Gay, and Bisexual Populations: Conceptual Issues and Research Evidence." Psychological Bulletin I 29(5): 675-97. https://doi.org/Io.1037/0033-2909.I29.5.674

Mossige, Svein, Kirsti Valset, Anne S. Grødem \& Helle Suseg. 2008. Seksuelle krenkelser via nettet - bvor stort er problemet? Oslo: Norsk institutt for forskning om oppvekst, velferd og aldring.

Muñoz, José Esteban. 2009. Cruising Utopia: The Then and There of Queer Futurity. New York: New York University Press.

Ohnstad, Anbjørg. 2009. Lesbiske identiteter: Skeive bevegelser. Doktorgradsavhandling. Psykologisk institutt, Universitetet i Oslo.

Perry, Barbara. 2014. "Exploring the community impacts of hate crime." I The Routledge International Handbook on Hate Crime, redigert av Nathan Hall, Abbee Corb, Paul Giannasi og John G. D. Grieve, 47-58. London: Routledge.

Plummer, Ken. 1995. Telling Sexual Stories. London \& New York: Routledge.

Sedgwick, Eve K. I990. Epistemology of the Closet. Berkeley \& Los Angeles: University of California Press.

Siverskog, Anna. 2016. Queera livslopp: Att leva och åldras som lhbtq-person i en heteronormativ värld. Doktorgradsavhandling. Institutionen för samhälls- och välfärdsstudier, Nationella institutet för forskning om äldre och åldrande. Linköpings universitet.

Siverskog, Anna \& Janne Bromseth. 20r9. "Subcultural Spaces: LGBTQAging in a Swedish Context". The International Journal of Aging and Human Development 88(4): 325-40. https://doi.org/IO.II77/oo91415019836923

Synnes, Oddgeir \& Kirsti Malterud. 2018. "Queer narratives and minority stress: Stories from lesbian, gay and bisexual individuals in Norway". Scandianvian Journal of Public Health 47(2): I05-I4. https://doi.org/ro.I I77/I4034948I875984I

Stubberud, Elisabeth \& Deniz Akin. 20I 8. Alene og skeiv? En studie av livssituasjonen for skeive enslige mindreårige asylsøkere i omsorgssentre og asylmottak. Nordfold: Forlaget Nora.

Stubberud, Elisabeth, Lin Prøitz \& Hasti Hamidias1. 2018. Den eneste skeive i bygda? Unge lhbt-personers bruk av kommunale helsetjenester. Nordfold: Forlaget Nora.

Thomson, Rachel, Robert Bell, Janet Holland, Sheila Henderson, Sheena McGrellis \& Sue Sharpe. 2002. "Critical Moments: Choice, Chance and Opportunity in Young 
People's Narratives of Transition." Sociology 36(2): 335-54. https://doi.org/I0.I I 77/oo 38038502036002006

van Wagenen, Aimee, Jeff Driskell \& Judith Bradford. 20I3. "'I'm Still Raring to Go':

Successful Aging among Lesbian, Gay, Bisexual, and Transgender Older Adults."

Journal of Ageing Studies 27(I): I-I 4. https://doi.org/Io.IoI6/j.jaging.20I 2.09.00I

\section{ABSTRACT}

What is being highlighted when queer people in Norway talk about their lives in the 2oros? In this article we analyse common denominators across qualitative interviews with 99 queer people with different backgrounds and in different life situations. Despite the many differences between the participants, there were some overarching themes that recurred and appeared significant across other differences: I) Experiences of feeling different, 2) negative encounters, 3) exploration of identity related to sexuality and gender, 4) coming out as queer, 5) coming into queer communities and 6) reflections on kinship and family. These important themes can be single events in time, at the same time as experiences are repeated throughout life both as events and by being recited as part of a queer life story. The events become significant beyond the time and place in which they happened and become part of a situated queer life story. We understand the six themes as queer metanarratives that participants draw on when they are talking about themselves as queer. In this article we explore these metanarratives and some of the significant variation in concrete experiences between participants. We argue that these important events tell us something about how we make ourselves recognisable as queer in the 20 Ios.

\section{NOTER}

I. Analysene i denne rapporten utgjør et delprosjekt i et større pågående forskningsprosjekt: "Lhbtis-levekår 2020 ". For mer informasjon om prosjektet, se https:// www.uib.no/lhbtis-levekar2020

2. Blant dem med innvandrerbakgrunn er alle verdensdeler med unntak av Oceania representert, men flertallet har bakgrunn fra Midtøsten. 